Dr. Németh Ernő* - Sárhidai Gyula

\title{
A vasúti tüzérség általános jellemzői és egyes típusai n.ressz
}

\section{Az M65-öS VASÚTI ÁGYÚ (AZ ÚN. ATOMÁGYÚ)}

Az US. Army a II. világháború alatt, több esetben a saját csapatain tapasztalta a nagy hatótávolságú német vasúti lövegek hatékony rombolását, ezért elhatározták egy ehhez hasonló eszköz legyártását. A háború végén az amerikai haderő igyekezett a lehető legtöbb német mérnököt és fegyvert összegyűiteni, majd ezek segítségével, ezekből kiindulva hozták létre saját típusaikat. Az új vasúti löveget is a német Krupp K5-ös vasúti löveg zsákmányolt példánya alapján építették.

A fejlesztése már 1944-ben megkezdődött, az Ordnance Department végezte a tervezést, legyártásával a Picatinny Arsenal műveket bízták meg.

A vállalat 1950-ben készítette el az M65 jelzésű löveget, amelyet az Atomic Annie névre kereszteltek (mivel a löveget a későbbiekben atomtöltettel rendelkező speciális lőszer kilövésére is alkalmassá kívánták tenni). A név maga is utalás volt a német K5-ös vasúti lövegre (amelyet a német haderő az olasz Anzio városa mellett vetett be, emiatt az eszközt a szövetséges hatalmak Anzio Annie néven ismerték.)

Az Atomic Annie készítői átvették a K5-ös löveg főbb szerkezeti megoldásait és ürméretét is. Korai megnevezése nehéz gépvontatású ágyú volt, ugyanis az M65-ös egy-egy M-249-es, illetve M-250-es kerekes jármű segítségével közúton is közlekedhetett -, mégis inkább vasúton közlekedő eszköz, lényegében vasúti löveg volt. Összesen 20 db M65-ös épült 800000 dolláros darabonkénti áron. Koreában és az európai NATO-államokban is teljesített szolgálatot. 1963-ban vonták ki a hadrendből.

Európában a 7. amerikai hadsereg tartotta hadrendben, Ázsiában a Dél-Koreában állomásozó amerikai megszálló

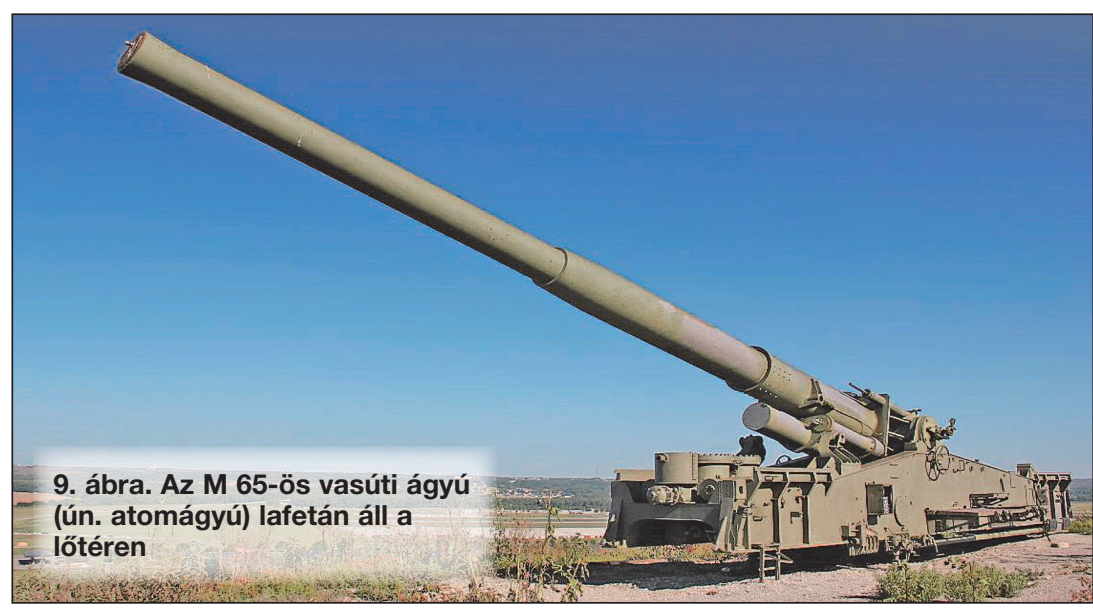

3. táblázat. Az M65-ös vasúti ágyú főbb műszaki adatai

\begin{tabular}{|l|c|}
\hline Név & M65 Atomic Annie \\
\hline Típus & nehéz gépvontatású ágyú \\
\hline Löveg & $780 \mathrm{~mm}$; L/46-os T131, bölcsőben \\
\hline Teljes tömeg & $42638 \mathrm{~kg}$ \\
\hline $\begin{array}{l}\text { Tüzelöállásban } \\
\text { a tömeg }\end{array}$ & $26,0 \mathrm{~m}$ (vasúti) \\
\hline Hosszúság & $3,12 \mathrm{~m}$ \\
\hline Szélesség & $3,20 \mathrm{~m}$ \\
\hline Magasság & $-0^{\circ}+55^{\circ}$ \\
\hline Csőemelkedés & $28,5 \mathrm{~km}, \mathrm{max} .30 \mathrm{~km}$ \\
\hline Oldalirányzás & $15^{\circ}$ finom / $360^{\circ}$ forgatásos \\
\hline Kezdősebesség & $762 \mathrm{~m} / \mathrm{s}$ \\
\hline Lőtávolság & $450 \mathrm{~kg}$ (nukleáris) \\
\hline Lövedék-tömeg & $70 ̋$ \\
\hline Kezelőszemélyzet & \\
\hline
\end{tabular}

csapatok. Ezek a kommunista erők sakkban tartására szolgáltak.

Az M65-ös központi eleme a T131-es löveg volt A löveg tüzelhetett hagyományos, HE (nagy robbanóerejü) lőszerrel, illetve a W9-es és W19-es nukleáris lőszerekkel is. A tüzeléskor fellépő jelentős erők miatt az M65-ös löveget nagy méretű csillapító és helyretolószerkezettel építették, valamint a csövet tartó bölcső is robusztus volt.

A 78000 kg-os M65-ös lövegnél a löveget és a talprészt általában speciális vasúti kocsin szállították, majd egy előre elkészített lőállásban helyezték el. Az Atomic Annie első atom-lövészetére 1953-ban került sor a Nevada sivatagban, amikor egy M65-ös löveg kilőtt egy nukleáris lőszert. Ez volt az első eset a világon, amikor hagyományos, csöves tüzérségi eszköz nukleáris töltettel tüzelt.

Az M65-ös sikeresen célba juttatta az „atom-lőszert”, amely 19 másodperccel a tüzelés után robbant fel, mintegy $10 \mathrm{~km}$-es távolságban. A lőszer 15 kilotonnás ha-

A hadtudományok kandidátusa, címzetes főiskolai tanár, Magyar Logisztikai Egyesület 


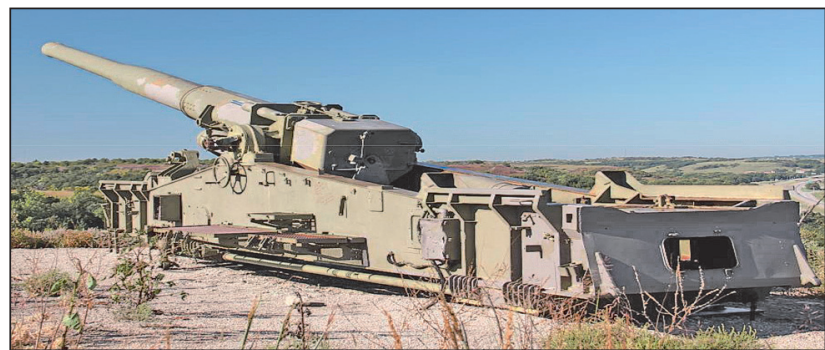

10. ábra. Az M 65-ös vasúti ágyú hátsó-oldalnézetből

tóerejű volt, ez közel azonos a Hirosimára ledobott atombomba erejével. Végül a hadvezetés belátta, hogy ezeket a lövegeket nem lehet nukleáris lőszerrel kombinálni és az ilyen programokat leállították. Ennek ellenére az M65ösöket csak tízévnyi szolgálat után, 1963-ban vonták ki végleg a szolgálatból.

(Meg kell állapítanunk, hogy ez a helyzet az 1970-es évek közepéig fennállt, de később a hosszú csövű M107-es 175 mm-es, az új $155 \mathrm{~mm}$-es M109A3-as és $210 \mathrm{~mm}$-es M110A2-es lövegek már rutinszerüen alkalmasak voltak miniatürizált nukleáris lőszerek kilövésére. Ezekből az M109-es és M110-es változatok ma is hadrendben állnak, vasúti löveg azonban több nem épült.)

\section{A BRIT BL 18 INCH-ES MK. I. VASÚtI TARACK}

A legnehezebb brit vasúti löveget még az I. világháború során tervezték, a nyugati front tapasztalatai alapján. Ez a legnehezebb brit vasúti ágyú lett volna, de késve készült el, és csak 1920-ban került szolgálatba.

Megnevezése Ordnance BL 18 inch Mk. I. tarack, vasút járművön. Az Elswick Ordnance Company, Royal Gun Factory gyára építette meg, de 1925-ig csak 5 db cső készült el. Ebből 2 db komplett vasúti alépítményt kapott, 3 cső tartalék maradt.

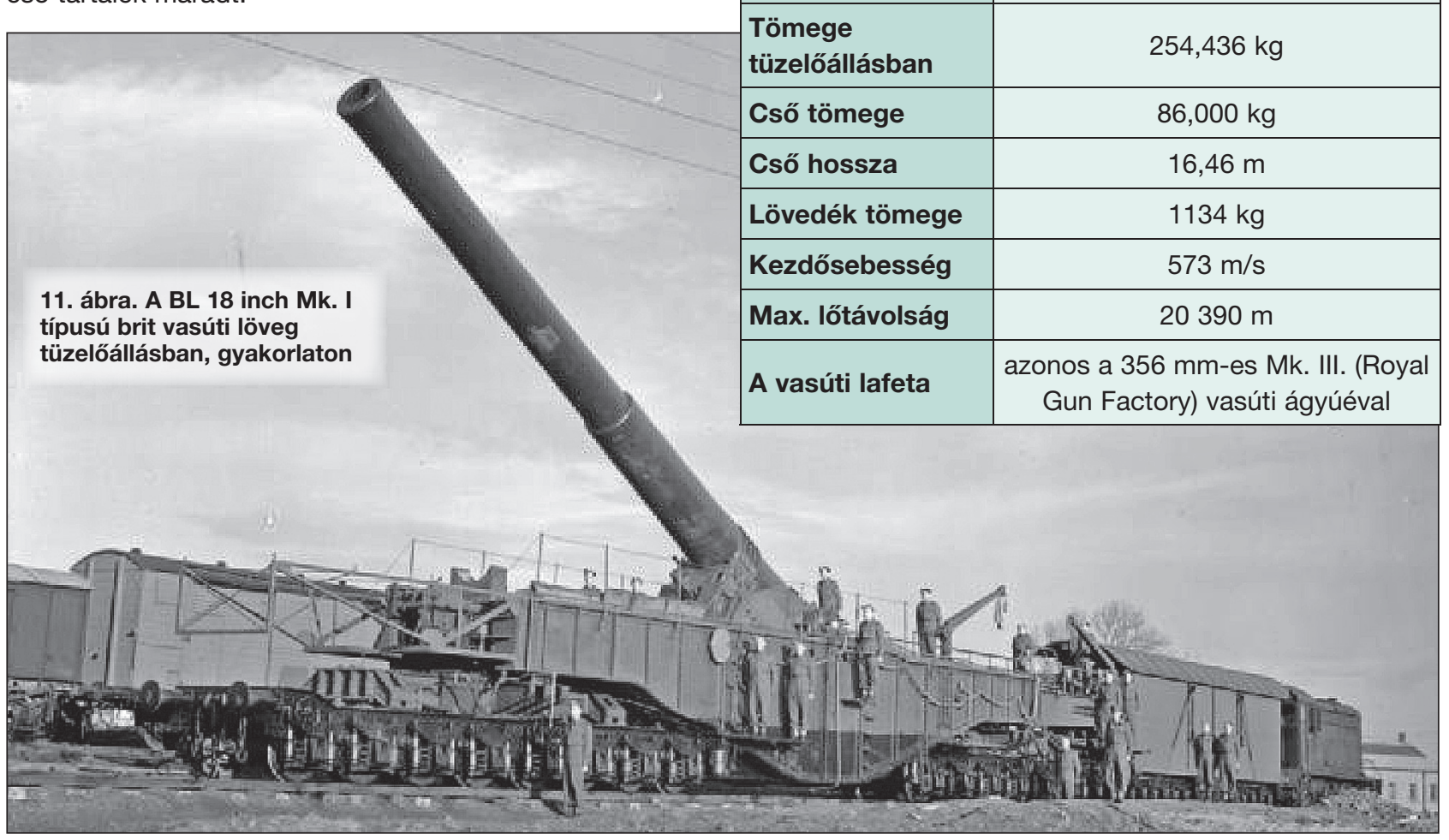

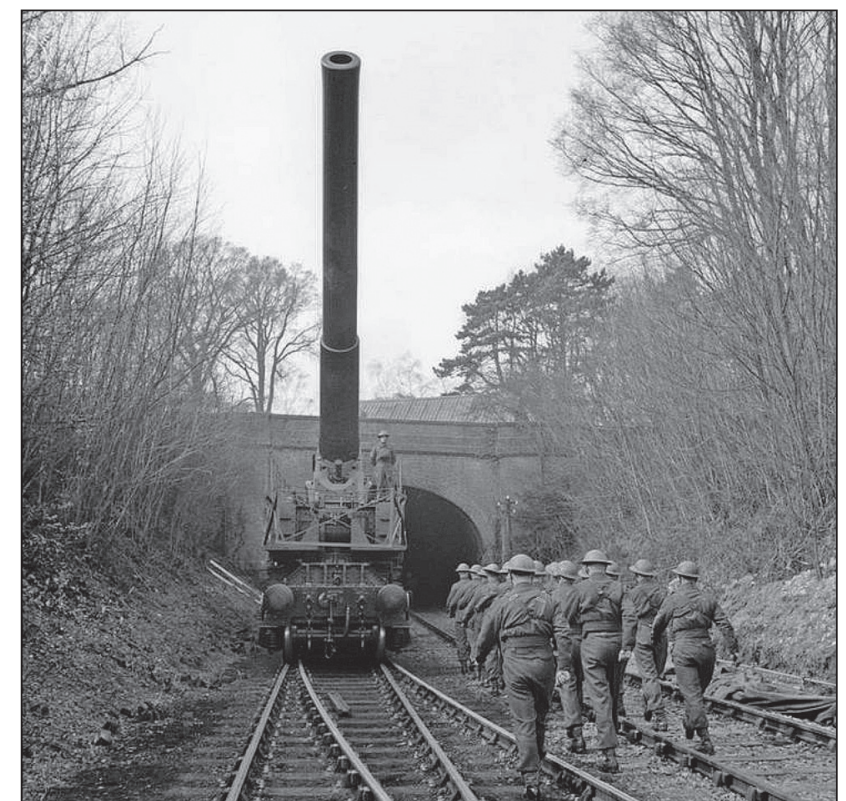

12. ábra. Hadgyakorlaton a brit löveg, tüzelés közben

$A z$ I. világháború után nem volt szerepkörük a relatív rövid hatótávolságú, de nehéz fegyvereknek és tartalékba kerültek egy raktárban. A II. világháború elején két vagonjára régebbi 343 mm-es (13,5 inch) ágyúkat szereltek fel. Ezekkel el lehetett érni a francia szigeteket a La Manche csatornában, amelyeket a német erők megszálltak.

4. táblázat. A 18 inch Mk. I. vasúti tarack föbb múszaki adatai

\begin{tabular}{|l|c|}
\hline Cső úrmérete & $452,2 \mathrm{~mm}$; L/36 $-0^{\circ}$ \\
\hline Csőemelkedés & $+40^{\circ}$ \\
\hline Oldalirányzás & $254,436 \mathrm{~kg}$ \\
\hline $\begin{array}{l}\text { Tömege } \\
\text { tüzelőállásban }\end{array}$ & $86,000 \mathrm{~kg}$ \\
\hline Cső tömege & $16,46 \mathrm{~m}$ \\
\hline Cső hossza & $1134 \mathrm{~kg}$ \\
\hline Lövedék tömege & $573 \mathrm{~m} / \mathrm{s}$ \\
\hline Kezdősebesség & $20390 \mathrm{~m}$ \\
\hline Max. lötávolság & $\begin{array}{c}\text { azonos a 356 mm-es Mk. III. (Royal } \\
\text { Gun Factory) vasúti ágyúéval }\end{array}$ \\
\hline A vasúti lafeta
\end{tabular}


